\title{
Identification and Optimisation of Lipase-Catalysed Synthesis of Betulinic Acid Amide in a Solvent System
}

\author{
Nurul Atikah Binti Amin Yusof, ${ }^{1}$ Nursyamsyila Mat Hadzir, ${ }^{1}$ and Siti Efliza Ashari ${ }^{2}$ \\ ${ }^{1}$ Applied Chemistry, Faculty of Applied Science, Universiti Teknologi MARA, 40450 Shah Alam, Selangor, Malaysia \\ ${ }^{2}$ Department of Chemistry, Faculty of Science, Universiti Putra Malaysia (UPM), Serdang, Selangor, Malaysia \\ Correspondence should be addressed to Nursyamsyila Mat Hadzir; nursyamsyila@salam.uitm.edu.my
}

Received 11 April 2016; Accepted 30 May 2016

Academic Editor: Ming-Jer Lee

Copyright (c) 2016 Nurul Atikah Binti Amin Yusof et al. This is an open access article distributed under the Creative Commons Attribution License, which permits unrestricted use, distribution, and reproduction in any medium, provided the original work is properly cited.

\begin{abstract}
Betulinic acid amide was synthesized from the enzymatic reaction of betulinic acid and butylamine catalysed by Novozym 435 . The effects of different reaction parameters, such as effect of reaction time, reaction temperature, amount of enzyme, and substrate molar ratio (betulinic acid : butylamine), were studied and conventionally optimised. Based on this study, the enzymatic synthesis of betulinic acid amide was found to be $64.6 \%$ at the optimum conditions of $24 \mathrm{~h}, 40^{\circ} \mathrm{C}, 100 \mathrm{mg}$ enzyme, and $1: 1$ substrate molar ratio in 9:1 mixture of chloroform and hexane as solvent. The identification of final product was carried out using TLC, melting point, and FTIR and NMR showed the presence of betulinic acid amide.
\end{abstract}

\section{Introduction}

Betulinic acid (BA), 3 $\beta$-hydroxy-lup-20(29)-en-28-oic acid (Figure 1), is a natural product that exhibits potent antitumor activities by triggering the mitochondrial path to apoptosis. Mitochondrion-targeted agents such as betulinic acid may open new perspectives to overcome some forms of drug resistance. Betulinic acid has attracted the science community's attention for its medicinal applications.

Betulinic acid is a naturally occurring pentacyclic triterpenoid which has broad range of biological properties such as anticancer, anti-inflammatory, anti-HIV, antimicrobial, and antimalarial activities [1]. In addition to that, it was shown that betulinic acid possesses a high toxicity towards cancer cells and a weak toxicity to healthy cells thus allowing a selective destruction of melanoma cells by apoptosis [2].

In the pharmaceutical industry, the medical uses of betulinic acid are strongly limited due to its poor solubility in water $(0.02 \mathrm{mg} / \mathrm{mL})$ which may contribute to the difficulty in absorption by the human body. It has been reported that the betulinic acid has three active sites, C- 3 hydroxyl group, C-20 alkene, and C-28 carboxyl group which are suitable for derivatization. The modification or introduction of polar groups such as phthalates, amino acids, or sugar moieties at the C-3 and C-28 positions of betulinic acid in certain cases may increase its hydrosolubility and its anticancer activities [3]. Unfortunately, derivatization at C-20 position is not an advantageous site to derivatize due to the loss of its cytotoxicity activity [4].

The organic reaction method for the synthesis of 3-Oacyl betulinic acid ester has been described by Mukherjee et al. [5], that give the formation of many by-products (difficult purification step was required and high energy consumption) [6]. Ghaffari Moghaddam et al. [3] reported that conventional esterification method of betulinic acid normally occurred at high temperature and results in complex mixture in the presence of acid and alkaline which leave traces in the product. However, the application of enzymes in organic synthesis provides a lot of advantages compared to conventional method since the reaction required in mild reaction condition, high selectivity, high catalytic efficiency, and high product purity and quality. The use of organic solvent lipase in organic media has exhibited many advantages such as increased activity and stability, regiospecificity and stereoselectivity, higher solubility of substrate, ease of products recovery, and the ability to shift the reaction [7]. 


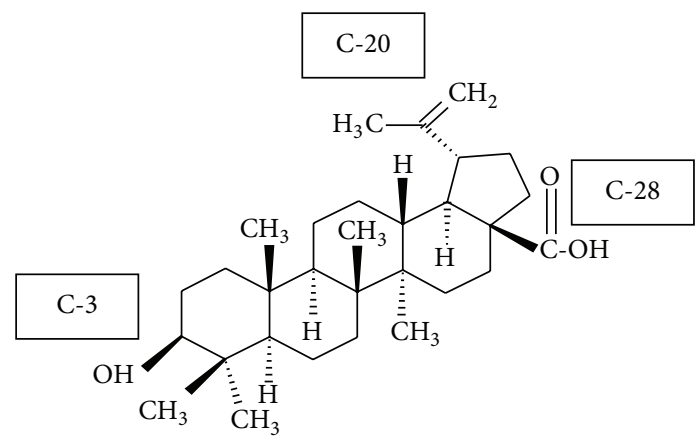

FIGURE 1: Structure of betulinic acid.

The aim of this study was to improve the percentage yield of enzymatic amidation reaction by optimising parameters such as reaction time, reaction temperature, enzyme amount, and substrate molar ratio. Figure 2 depicts the enzymatic reaction of betulinic acid and butylamine in the presence of Novozym 435.

\section{Materials}

2.1. Enzyme. Immobilised lipase (triacylglycerol hydrolase, EC 3.1.1.3; Novozym 435, 1000 PLU g-1) from Candida antarctica, supported on a macroporous acrylic resin with water content of $3 \%(\mathrm{w} / \mathrm{w})$, was purchased from Novo Nordisk A/S (Bagsvaerd, Denmark).

2.2. Chemicals. Betulinic acid was isolated from Malaysian Callistemon sp. as reported in Ahmad et al. [8]. Butylamine, ethyl acetate, chloroform, hexane, and methanol were purchased from Merck, Germany. All other reagents were of analytical grade.

\section{Methods}

3.1. Enzymatic Synthesis. Betulinic acid ( $22.8 \mathrm{mg}, 0.05 \mathrm{mmol})$ and butylamine $(3.66 \mathrm{mg}, 0.05 \mathrm{mmol})$ were placed in capped reaction vials. Chloroform and hexane $(9: 1)$ were added into the reaction mixture and stirred until all the reactants dissolved. Novozym 435 (100 mg) was then added into the reaction vials. Reaction mixtures were incubated at $40^{\circ} \mathrm{C}$ and $150 \mathrm{rpm}$ for $24 \mathrm{~h}$ in a horizontal water bath shaker (Memmert WB14, Germany). Each reaction was repeated in triplicate and average values $(\mathrm{mg}$ ) of products were reported. Control experiments were performed in the absence of enzyme.

\subsection{Analytical Method}

3.2.1. TLC Analysis. Preliminary detection and identification of reaction products were carried out using Thin Layer Chromatography (TLC) with n-hexane/ethyl acetate $(7: 3$, $\mathrm{v} / \mathrm{v}$ ) as the eluent. The plates were visualized under UV lamp and potassium permanganate $\left(\mathrm{KMnO}_{4}\right)$ stain. The solvent was evaporated and chromatographed with gradient on silica gel 60 (n-hexane/ethyl acetate, 9:1-5:1v/v). Then, the percentage of isolated yield was calculated.
3.3. Identification of Reaction Product (BAA). IR spectrum was recorded using Perkin-Elmer FTIR model where samples were prepared by using KBR pellet. ${ }^{1} \mathrm{H}$ spectra were recorded on BRUKER NMR spectrometer instrument operating at the frequency of $600 \mathrm{MHz}$. Samples weighed approximately 10$20 \mathrm{mg}$ and were dissolved in deuterated solvent, $\mathrm{CDCl}_{3}$. The melting point of the reaction product was determined by using Electrothermal-MEL TEMP. For a pure compound, the difference between the temperature ranges was only about 1$2^{\circ} \mathrm{C}$.

\subsection{Optimisation Study of Lipase-Catalysed Reaction of Betulinic Acid Amide}

3.4.1. Effect of Reaction Time. The reaction mixtures consist of betulinic acid ( $22.8 \mathrm{mg}, 0.05 \mathrm{mmol}$ ), and butylamines ( $3.66 \mathrm{mg}, 0.05 \mathrm{mmol}$ ) were placed in the capped reaction vials. Chloroform : hexane $(10 \mathrm{~mL})$ was added to the reaction mixture and stirred until all the reactants were dissolved. Novozym 435 (100 mg) was added and the incubation was carried out at $40^{\circ} \mathrm{C}$ and $150 \mathrm{rpm}$ at different reaction times (4, $8,12,24,48$, and $72 \mathrm{~h}$ ). The percentage yield (\%) of betulinic acid amide (BAA) is defined as the number of moles of BAA produced over the initial number of moles of betulinic acid used.

3.4.2. Effect of Reaction Temperature. The effect of different reaction temperatures $\left(37,40,50\right.$, and $\left.60^{\circ} \mathrm{C}\right)$ on BAA synthesis was studied.

3.4.3. Effect of Amount of Enzyme Used. The effect of different amounts of enzyme (50,100,150, 200, and $250 \mathrm{mg}$ ) on the BAA synthesis was investigated by varying the enzyme amount.

3.4.4. Effect of Molar Ratio of Amines. The reaction was repeated using betulinic acid with different molar ratios of butylamines $(1: 1,1: 2,1: 3$, and $1: 4)$ and placed in the capped reaction vials.

\section{Results and Discussion}

4.1. Identification of BAA. The BAA product obtained after purification appeared to be yellowish crystal with melting point in the range of $308-310^{\circ} \mathrm{C}$. TLC analysis was carried out and the BAA product had $R_{f}$ value of 0.88 (Figure 3 ). The formation of BAA monitored by FTIR showed N-H stretching at $3365 \mathrm{~cm}^{-1}$ and $1710 \mathrm{~cm}^{-1}$ indicated the presence of the carbonyl group $(\mathrm{C}=\mathrm{O})$ of amides. ${ }^{1} \mathrm{H}$ NMR spectra data of betulinic acid amide were recorded using Varian Unity Inova $600 \mathrm{MHz} \mathrm{NMR}$ spectrometer (Figure 4). $\left(\mathrm{CDCl}_{3}\right.$, $600 \mathrm{MHz}): \delta 0.754$ (H-23), $0.822(\mathrm{H}-24), 0.937$ (H-25), 0.965 (H-26), $0.974(\mathrm{H}-27), 1.690(\mathrm{H}-30)$ each $3 \mathrm{H}, \mathrm{s}, 6 \times \mathrm{CH}_{3}, 3.183$ $(1 \mathrm{H}, \mathrm{m}), 3.598(\mathrm{~J}=7.8, \mathrm{NH}, \mathrm{s}), 2.628,2.693,2.762(\mathrm{H} 1,2 \mathrm{H}, \mathrm{t})$, 0.917, 0.930, $0.941(\mathrm{H} 2,3 \mathrm{H}, \mathrm{t})$.

\subsection{Optimisation Study}

4.2.1. Effect of Reaction Time. Figure 5 shows the reaction time for enzymatic amidation reaction of betulinic acid with 


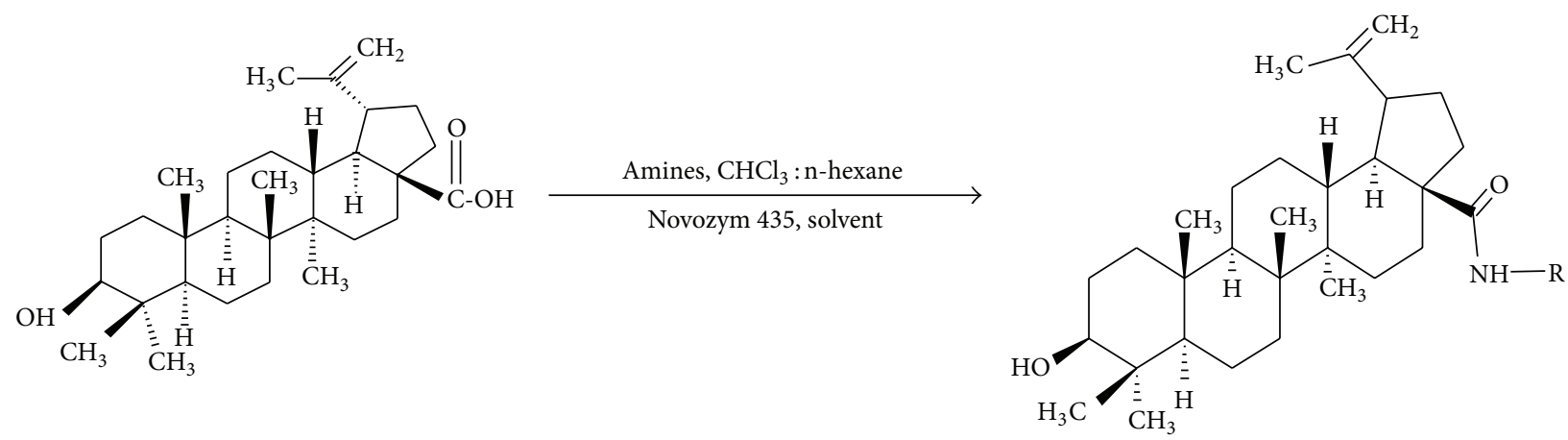

Figure 2: Enzymatic synthesis of betulinic acid amide (BAA).

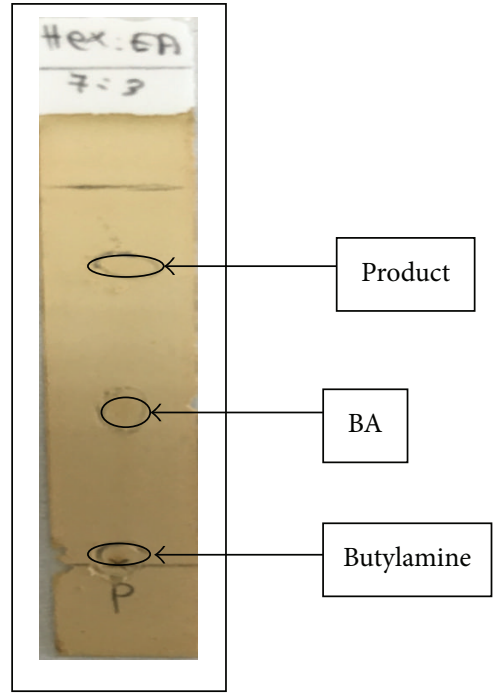

FIgURe 3: TLC spot.

butylamine $(1: 1)$ ratio and Novozym 435 as biocatalyst. It was observed that the rate of reaction and overall conversion increase with increasing reaction time until it reached $24 \mathrm{~h}$. As the reaction time was prolonged up to $24 \mathrm{~h}$, the percentage yield was decreased probably due to the reduction of saturation of enzyme with substrate which means it has achieved its equilibrium state [3].

4.2.2. Effect of Reaction Temperature. By increasing the reaction temperature, substrate solubility was found to be improving by reducing mass transfer limitations and making the substrate more available to the enzyme [3]. Figure 6 shows the percentage yield increased with increasing temperature and reached the maximum percentage yield $(64.6 \%)$ at $40^{\circ} \mathrm{C}$. The conversion was then reduced when temperature increased from $50^{\circ} \mathrm{C}$ to $60^{\circ} \mathrm{C}$ and this is probably due to deactivation of lipase beyond its critical temperature [9]. The temperature of BAA synthesis was selected below $60^{\circ} \mathrm{C}$ to prevent the disruption of enzyme tertiary structure and also reduction of catalytic activity of the enzyme [10].

4.2.3. Effect of Amount of Enzyme. The effect of amount of enzyme was studied by varying the amount of enzyme added to the reaction mixture. Figure 7 depicts the percentage yield increased dramatically and reached maximum yield $64.6 \%$ by addition of $100 \mathrm{mg}$ of enzyme for $0.05 \mathrm{mmol}$ of betulinic acid used. However, the percentage yield slightly decreased by addition of enzyme from 150 to $250 \mathrm{mg}$. The result showed that the excess amount of enzyme did not contribute to achieving high yield of product; it may be due to the substrate limitation and enzyme itself could also cause mass transfer limitation [3]. A similar trend has been reported by Jumbri et al. [11] and it mentioned that steric hindrance will occur with excessive amount of enzyme.

4.2.4. Effect of Amount of Substrate (Molar Ratio). Figure 8 shows the effect of amount of substrate at which betulinic acid was studied at constant mole $(0.05 \mathrm{mmol})$ while the mole of butylamine is varied. From Figure 8, 1:1 molar ratio of betulinic acid to butylamine produced the highest percentage yield $(64.6 \%)$ compared to other molar ratios. The result shows that the increasing concentration of substrate did not increase the percentage yield due to excess of butylamine. It will hinder the interaction between substrate and enzyme and also led to deactivation of enzyme. According to Krishna et al. in 2001, excess substrate may lead to deactivation of enzyme by dissolution in microaqueous phase or act as competitive inhibitor [12].

\section{Conclusion}

The enzymatic synthesis of betulinic acid amide has been studied and focused on the effect of different operating variables (reaction time, reaction temperature, enzyme amount, and substrate molar ratio). It was shown that the catalytic activity increased by increasing the reaction time up to $24 \mathrm{~h}$ and also increasing the reaction temperature up to $40^{\circ} \mathrm{C}$ does not cause loss in the enzyme activity. The maximum 

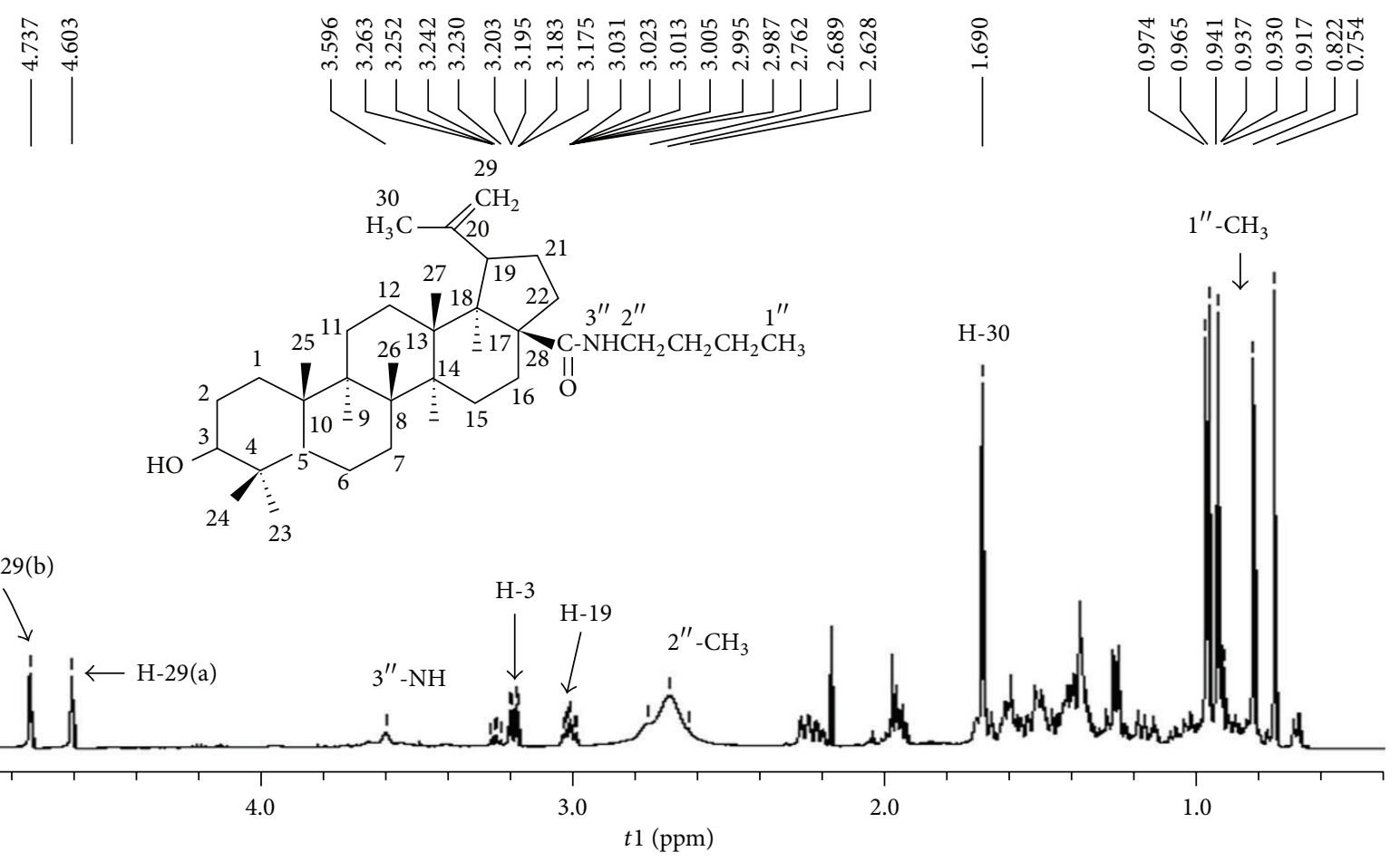

Figure $4:{ }^{1} \mathrm{H}$ proton NMR of BAA.

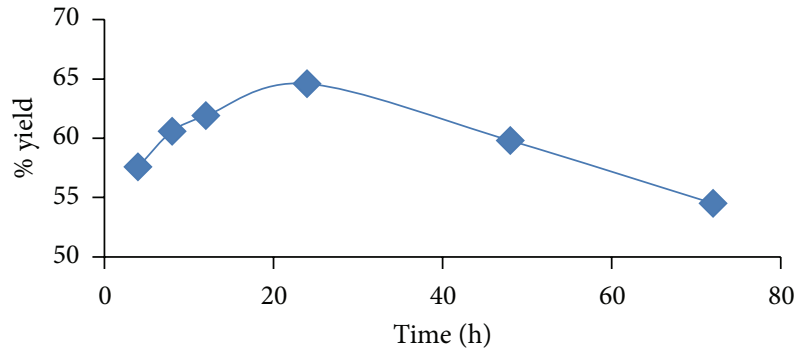

FIGURE 5: Effect of reaction time (reaction conditions: Novozym 435, $100 \mathrm{mg}$; temperature, $40^{\circ} \mathrm{C}$; agitation speed, $150 \mathrm{rpm}$ ).

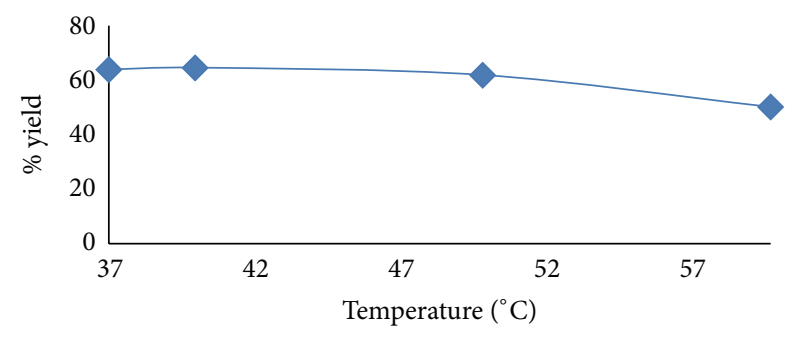

FIGURE 6: Effect of reaction temperature (reaction conditions: Novozym 435, $100 \mathrm{mg}$; time, $24 \mathrm{~h}$; agitation speed, $150 \mathrm{rpm}$ ).

percentage of betulinic acid amide produced was $64.6 \%$ with substrate molar ratio $1: 1$ and enzyme amount $100 \mathrm{mg}$ for $24 \mathrm{~h}$ at $40^{\circ} \mathrm{C}$. The identification structure of BAA was revealed by using TLC, MP, FTIR, and NMR spectroscopy.

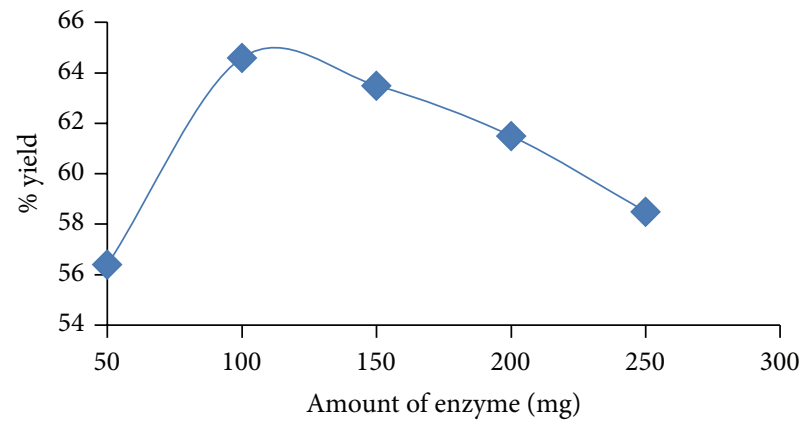

FIGURE 7: Effect of amount of enzyme (reaction conditions: temperature, $40^{\circ} \mathrm{C}$; time, $24 \mathrm{~h}$; agitation speed, $150 \mathrm{rpm}$ ).

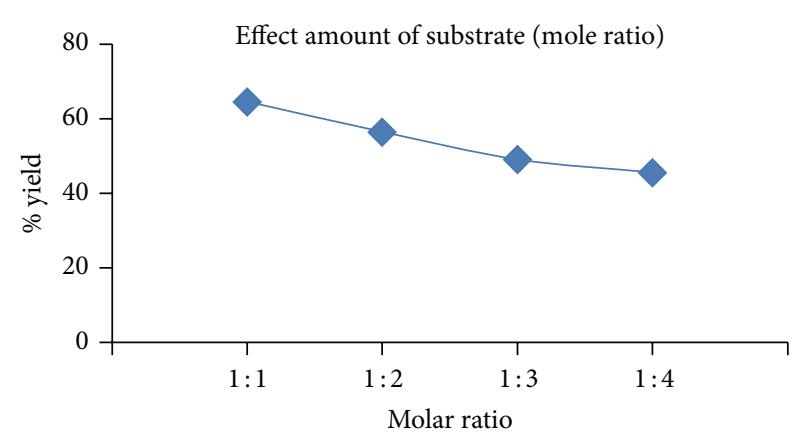

FIGURE 8: Effect of amount of substrate (reaction conditions: temperature, $40^{\circ} \mathrm{C}$; time, $24 \mathrm{~h}$; Novozym 435, $100 \mathrm{mg}$; agitation speed, $150 \mathrm{rpm})$. 


\section{Glossary of Terms}

Competitive inhibitor: It is an inhibitor that occupies the active site of an enzyme or the binding site of a receptor and prevents the normal substrate or ligand from binding.

Catalytic activity: It is the increase in the rate of a specified chemical reaction caused by an enzyme or other catalysts under specified assay conditions.

Deactivation of enzyme: It is the enzyme changes in the structure of a neurotransmitter so that it is no longer recognized (inactive) by the receptor.

Equilibrium state: It is the point at which the concentrations of reactants and products do not change with time; forward and reverse reactions are equal so reactants and products are being created at the same rate.

Steric hindrance: It is the higher energy price (and slower reaction rate) due to the approach of larger atoms or groups in a chemical reaction, compared to a similar reaction involving smaller atoms or groups.

\section{Competing Interests}

The authors declare that they have no competing interests.

\section{Acknowledgments}

The authors wish to thank Professor Dr. Faujan Hj Ahmad, all the staff in the Faculty of Applied Science of Universiti Teknologi MARA, and the staff in the Department of Chemistry of Universiti Putra Malaysia for the help in this study.

\section{References}

[1] P. Yogeeswari and D. Sriram, "Betulinic acid and its derivatives: a review on their biological properties," Current Medicinal Chemistry, vol. 12, no. 6, pp. 657-666, 2005.

[2] R. Csuk, K. Schmuck, and R. Schäfer, "A practical synthesis of betulinic acid," Tetrahedron Letters, vol. 47, no. 49, pp. 87698770, 2006.

[3] M. Ghaffari Moghaddam, F. B. H. Ahmad, M. Basri, and M. B. Abdul Rahman, "Lipase-catalyzed esterification of betulinic acid using phthalic anhydride in organic solvent media: study of reaction parameters," Journal of Applied Sciences, vol. 10, no. 4, pp. 337-342, 2010.

[4] J. Y. Kim, H.-M. Koo, and D. S. H. L. Kim, "Development of C-20 modified betulinic acid derivatives as antitumor agents," Bioorganic and Medicinal Chemistry Letters, vol. 11, no. 17, pp. 2405-2408, 2001.
[5] R. Mukherjee, M. Jaggi, P. Rajendran et al., "Synthesis of 3-Oacyl/3-benzylidene/3-hydrazone/3-hydrazine/17-carboxyacryloyl ester derivatives of betulinic acid as anti-angiogenic agents," Bioorganic \& Medicinal Chemistry Letters, vol. 14, no. 12, pp. 3169-3172, 2004.

[6] Y. Yasin, M. Basri, F. B. H. Ahmad, and A. B. Salleh, "Response surface methodology as a tool to study the lipase-catalyzed synthesis of betulinic acid ester," Journal of Chemical Technology and Biotechnology, vol. 83, no. 5, pp. 694-698, 2008.

[7] S. H. Krishna, B. Manohar, S. Divakar, S. G. Prapulla, and N. G. Karanth, "Optimization of isoamyl acetate production by using immobilized lipase from Mucor miehei by response surface methodology," Enzyme and Microbial Technology, vol. 26, no. 2-4, pp. 131-136, 2000.

[8] F. B. H. Ahmad, J. Omar, and A. M. Ali, "Chemical examination of local plant: triterpene from leaf of Malaysian Callistemon speciosus D.E”, Ultra Science, vol. 11, pp. 357-359, 1999.

[9] S. M. Radzi, M. Basri, A. B. Salleh et al., "High performance enzymatic synthesis of oleyl oleate using immobilised lipase from Candida antartica," Electronic Journal of Biotechnology, vol. 8, no. 3, pp. 291-298, 2005.

[10] M. D. Romero, L. Calvo, C. Alba, A. Daneshfar, and H. S. Ghaziaskar, "Enzymatic synthesis of isoamyl acetate with immobilized Candida antarctica lipase in $n$-hexane," Enzyme and Microbial Technology, vol. 37, no. 1, pp. 42-48, 2005.

[11] K. Jumbri, M. F. A. H. Rozy, S. E. Ashari, R. Mohamad, M. Basri, and H. R. Fard Masoumi, "Optimisation and characterisation of lipase-catalysed synthesis of a kojic monooleate ester in a solvent-free system by response surface methodology," PLoS ONE, vol. 10, no. 12, Article ID e0144664, 2015.

[12] S. H. Krishna, S. Divakar, S. G. Prapulla, and N. G. Karanth, "Enzymatic synthesis of isoamyl acetate using immobilized lipase from Rhizomucor miehei," Journal of Biotechnology, vol. 87, no. 3, pp. 193-201, 2001. 

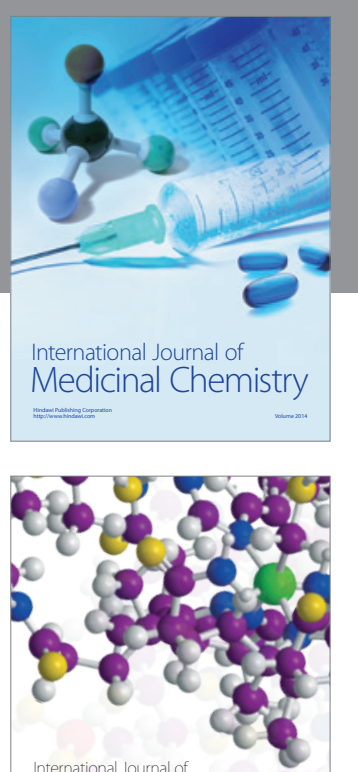

Carbohydrate Chemistry

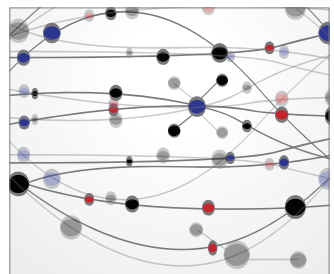

The Scientific World Journal
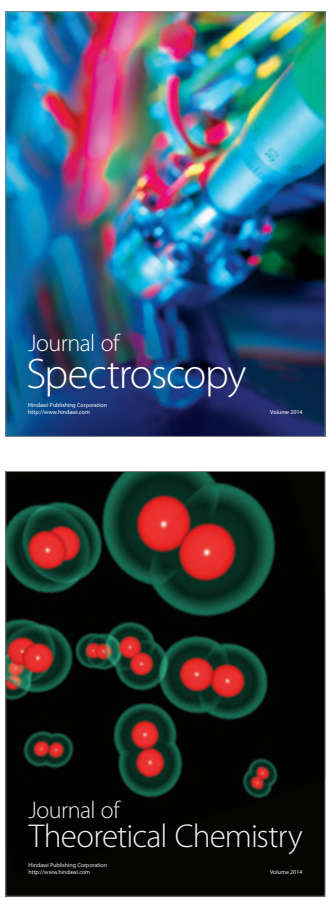
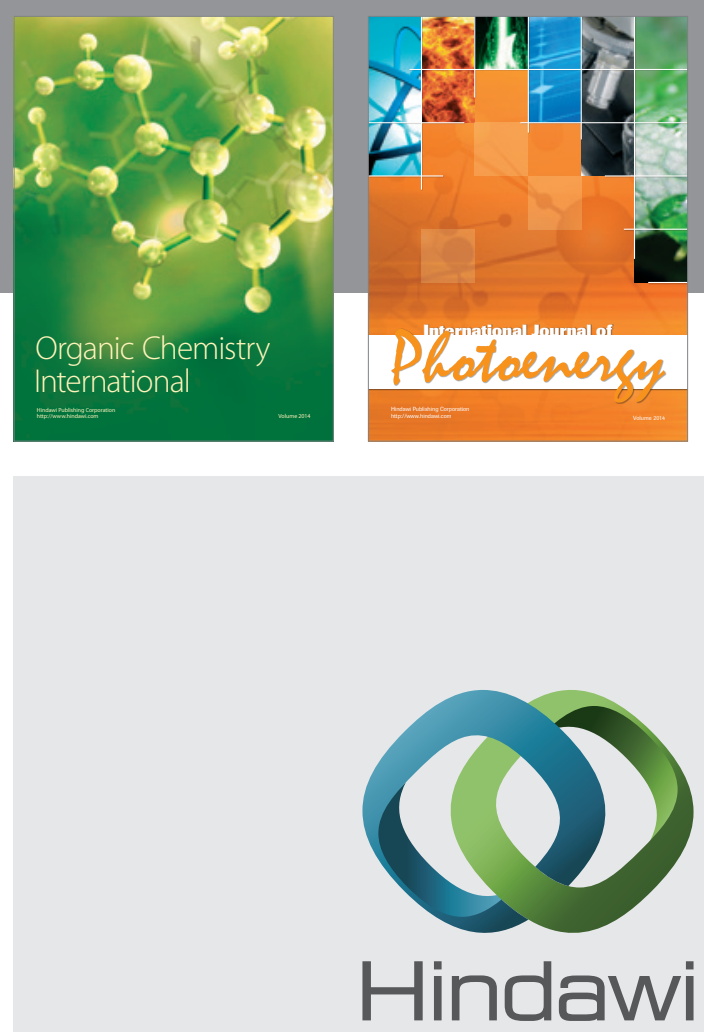

Submit your manuscripts at

http://www.hindawi.com

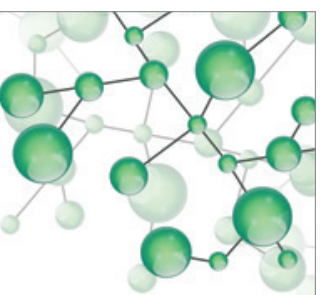

International Journal of

Inorganic Chemistry

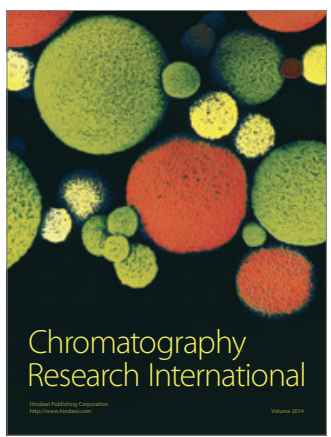

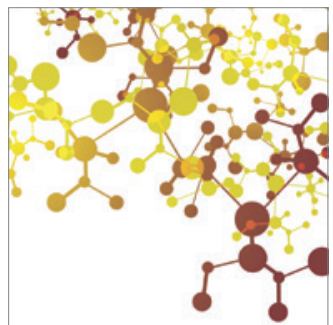

Applied Chemistry
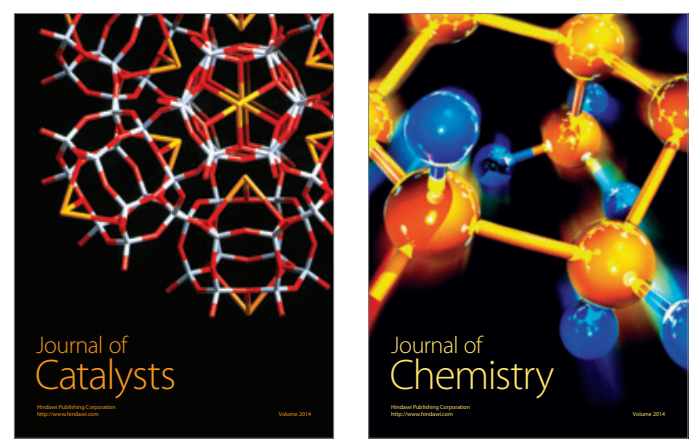
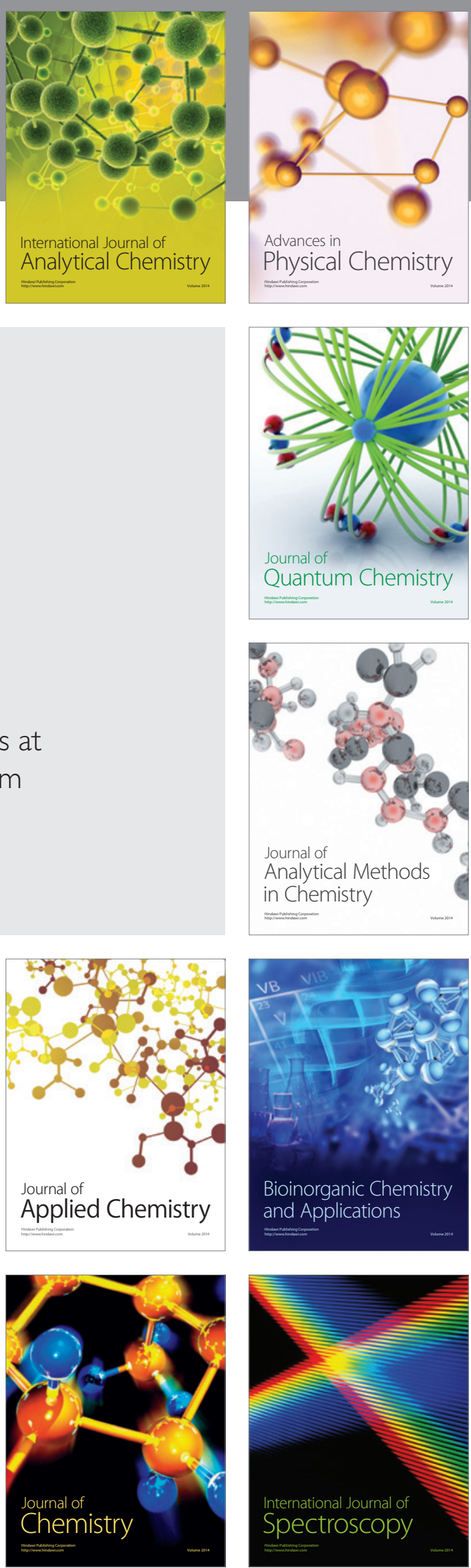